\title{
Black Workers, Organized Labor, and the Struggle for Civil Rights
}

\section{William P. Jones,}

University of Wisconsin-Milwaukee

Beth Tomkins Bates, Pullman Porters and the Rise of Protest Politics in Black America, 1925-1945 (Chapel Hill: University of North Carolina Press, 2001).

Andrew Edmund Kersten, Race, Jobs, and the War: The FEPC in the Midwest, 1941-46 (Urbana: University of Illinois Press, 2000).

Michael Keith Honey, Black Workers Remember: An Oral History of Segregation, Unionism, and the Freedom Struggle (Berkeley: University of California Press, 1999).

Gail Williams O'Brien, The Color of Law: Race, Violence, and Justice in the Post-World War II South (Chapel Hill: University of North Carolina Press, 1999).

Timothy J. Minchin, The Color of Work: The Struggle for Civil Rights in the Southern Paper Industry, 1945-1980 (Chapel Hill: University of North Carolina Press, 2001).

For historians of the post-World War II United States, few questions have been so contentious as to whether white workers and union activists provided meaningful support for the struggle for black civil rights. Viewing unity between black and white workers as the bedrock of American liberalism, scholars have attributed to disunity everything from the end of the New Deal, to Reaganism, to Clinton's dismantling of Welfare. Debate has emerged primarily over the roots of declension, with several scholars arguing that rank and file racists limited the extent to which union leaders could endorse black equality. Employers, politicians, and civil rights activists also play roles of varying importance in these narratives. An important minority of scholars argue that anti-communism, which silenced the most vocally anti-racist whites, ended the possibility that organized labor would play a significant role in the civil rights movement. Since most see the nexus of race and class as critical to understanding modern American history, however, it is ironic that most scholars portray black workers themselves, if at all, as helpless bystanders in a battle waged by others.

As several recent publications demonstrate, one cannot understand the evolution of post-war liberalism without studying the social and political his- 
tory of working-class African Americans. Much more than beneficiaries of an expanding welfare state or victims of conservative backlash, black workers built unions, supported political movements, and initiated legal proceedings that contributed to, and at times detracted from, working-class support for the civil rights movement. As Beth Bates demonstrates in her study of the Brotherhood of Sleeping Car Porters (BSCP), some black workers first recognized unions as a potential weapon in the struggle against racism in the 1920s, even as neither the American Federation of Labor (AFL) nor the National Association for the Advancement of Colored People (NAACP) recognized their union. Strengthened by labor shortages and the democratic rhetoric of the Second World War, those black radicals won support from a wide spectrum of civil rights leaders, labor activists, and federal officials in the 1940s. As late as the 1970s, according to Timothy Minchin, black workers ensured that exclusion and segregation at work would emerge as a "central theme of the struggle for civil rights."

That the civil rights movement gained strength from the social democratic liberalism of the New Deal era is not a novel idea. What these works contribute is an understanding of how working-class African Americans participated in uniting racial and economic egalitarianism in the 1930s and 1940s. While previous studies of the Brotherhood have focused on its leader, A. Phillip Randolph, Bates provides a community study of the union's rise to influence in Chicago, first among Pullman Porters and later among a widening circle of black social and political activists. She traces the "protest politics" that brought Randolph notoriety in the 1940s to the Porters' rejection of paternalistic welfare strategies in the 1920s. By expanding workplace struggles with the Pullman Company into a broader "social movement" for racial equality, the BSCP established that rejection as a model for black political activism nationwide.

The politics of the BSCP were rooted not only in the anti-racist socialism of Randolph's Messenger, but also in a masculinist republican ideology forged in the defeat of Reconstruction. "We are willing to work and at the same time be courteous," a porter declared at a 1919 rally, "but we are going to insist that we are men and as such entitled to a living wage" (30). Asserting that "manhood rights" included the ability to provide economic security to their families and communities, the Brotherhood married Booker T. Washington's economic realism with the political liberalism of W.E.B. Du Bois. Such a marriage made sense to members of Chicago's Women's Club movement, who were among the city's first converts to the "New Crowd," as Randolph dubbed his supporters. Having devoted themselves to the welfare of their communities during the darkest years of Jim Crow, these women recognized the futility of separating economic and political rights. 
Bates could have pushed her gender analysis much farther. After several pages on Club leader Ida B. Well's endorsement of the Brotherhood's "manhood" campaign, Bates claims that racism did not allow black female activists "to think of breaking their work into categories of gender or class." Scholars on club women, including Deborah Grey White, who Bates quotes, however, have emphasized that gender and class ideologies remained central in the theory and practice of club work, precisely because for "black women, race, class, and gender issues were so inseparable that one could not work on one front without working on all three" (73). The point was not that racism made other distinctions less important, but that it transformed and intensified their meanings. ${ }^{1}$

Bates also never concludes her assessment of the Brotherhood's politics. Her final chapter, "Protest Politics Comes of Age," is set in Detroit, which gives her an interesting story but prevents her from following through with the analysis of Chicago in previous chapters. More importantly, she shifts her attention from Randolph and the porters to examine a labor-civil rights coalition that she claims was inspired by the Brotherhood's March on Washington Movement. This leads her to conclude that "the rise of protest politics was as significant for the experience black Americans gained trying out new strategies for taking control of their destiny, on their own terms, as for the changes it engendered in the racial status quo" [emphasis in original] (187). That may be true, but Bates gives readers little knowledge of those changes by which they could make such an assessment.

The BSCP's most significant attack on the status quo came through the creation of the Fair Employment Practice Committee (FEPC), by executive order of President Roosevelt on June 25, 1941. Roosevelt signed the order after Randolph convinced him that 100,000 black workers would march on Washington to demand access to jobs and political equality. A partial concession to the march, the FEPC was the first federal attempt to measure and eliminate discrimination by employers and unions in government contracted jobs. Bates dismisses the political significance of the FEPC, writing that because it "lacked enforcement power," it was "as important in terms of the tactics used to extract the order as for the recognition and acknowledgement by the federal government that American democracy failed to grant equal economic opportunity to all its citizens" (161).

As Andrew Kersten demonstrates, the FEPC was more effective than Bates (and many other scholars) believe. The Committee heard over twelve thousand cases between 1941 and 1946, settling nearly five thousand (42\%). Through 32 public hearings, committee members scrutinized the racial employment policies of 132 private companies, 38 labour unions, and 5 government agencies. Nearly two million minority workers found employment with the federal government during World War Two. While previous scholars have attributed this 
increase to intense labor shortages during the war, Kersten points out that complaints of discrimination came from cities such as Detroit and Cleveland even in the midst of severe labor shortages. Partially as a result of federal action, the African American percentage of defense employment increased from $2.5 \%$ to $8.3 \%$ between 1942 and 1944 . While black workers were the largest beneficiaries of the FEPC, Mexican Americans, Jews, and immigrants from various nations also utilized its services. Further evidence of the agency's effectiveness can be found in the opposition it elicited from Congressional conservatives, who denounced it as "communist nonsense," and an example of "Negro domination" that was "both unfair and intolerable"(129).

While Kersten attributes the FEPC's success to its being a "quintessential New Deal agency," his evidence indicates that it benefited more from black activism than from the efforts of the Roosevelt administration. The FEPC gained support from key employers and labour leaders in Chicago and Detroit, for example, where black union and civil rights activists lent experience and diplomatic support. In Ohio and Indiana, on the other hand, the agency found itself paralyzed by a solid front of conservative business and labour leaders. That the federal agency succeeded only through local support was further indicated by the proliferation of state and municipal fair employment offices where the federal agency did not operate. In Minneapolis, which was too far from Chicago to gain support from the FEPC's regional office, the Twin City Council on Fair Employment Practice met greater success than most of FEPC offices in the Midwest.

These findings support Kersten's comparison between the FEPC and earlier New Deal agencies such as the National Labor Relations Board (NLRB) and the Office of Price Administration that relied upon effected citizens to mobilize in support of government policy. ${ }^{2}$ Like the NLRB, the FEPC gained strength from workers who enforced the law themselves at the point of production. Readers may be familiar with the numerous "hate strikes" during World War Two, when white workers refused to work alongside blacks who were promoted under FEPC rulings. Less well known is that black workers also used strikes as a weapon against discrimination. In addition to bolstering federal mandates, Kersten speculates, strikes also ensured that "racial frustrations were channeled through job actions," rather than race riots as they were following the First World War (55). Even after conservatives defeated the FEPC in 1946, workers benefited from the legal and moral precedent set by the agency.

Michael Honey and Gail Williams O'Brien provide two case studies of the channeling of racial conflict into institutional settings during and after the war. As both black and white workers flocked from the rural South into rapidly industrializing Memphis, Tennessee, according to Honey, "new workplace 
opportunities opened up new struggles against Jim Crow" (123). Like Bates, Honey finds roots of these struggles in the "black civil rights consciousness" of Ida B. Wells and other early activists. "The opportunities for real change, emerged with World War II," however, as black workers found support for their demands within sectors of the federal government and organized labour (132). In the postwar period, black workers found in Memphis's CIO unions a powerful vehicle for linking civil rights and union struggles.

A collection of oral history interviews conducted during research for his monograph Southern Labor and Black Civil Rights, Honey's latest publication provides rich insight into black workers' own interpretations of that emergence. It is not clear that "the stories in this book tell us more than a sociological survey or archival study could," as Honey claims, but they do provide moving details about the experience and aspirations of African American working-people that have been overlooked in much of the published record (7). Union activist Clarence Coe recalls, for example;

I can remember the first time I saw a white man shake hands with a black man, down in Crenshaw, Mississippi. World War II had started. A black man in a uniform crossed the railroad track, and he stuck out his hand to a white man. They knew each other. Twenty or thirty years ago you didn't shake hands with a white man. If you did, the white man would be called a nigger lover (137).

Coe continues in moving detail about building the NAACP in Memphis in the 1930s, working at Firestone Tire and Rubber Company and organizing the United Rubber Workers Union during and after the war.

Lacking is analysis of the broader social and political changes that men and women like Coe were responding to when they devoted their lives to "civil rights unionism." Honey dismisses anti-Communism as a front for segregationism, for example, writing that "most black union activists rejected red-baiting as simply another means of driving equal rights advocates out of the unions and scaring away white workers" (178). It may be true that "many whites used the slur 'nigger lover' and 'Communist' interchangeably," but furniture worker Rebecca McKinley displayed a much more complex reasoning when she rejected offers to join the Communist Party on the grounds that "if you're going to live in this country, you shouldn't undermine it. I'm not for communism," she clarified, "but I'm not for this system either. Why do people have to be poor when we can go to the moon?"(120). In another example, when a bus driver told a group of black soldiers to move from the white sections, they proclaimed that "this is America" and threatened to beat him. One gets the sense, reading Honey's comments on his interviews, that black workers possessed a constant, 
single-minded obsession with higher wages and equal treatment. His interviews, however, provide insight into more historically rooted, often conflicted, ideological evolution.

By combining oral history interviews with extensive archival research, Gail O'Brien presents a richer explanation for the intensification of black political activism after the Second World War. If in Memphis, as Honey contends, "black workers had understandable hopes that the postwar period would set off major social change," this was not an assessment shared by most civil rights leaders nationally (133). White workers in several cities responded to federal anti-discrimination measures by attacking blacks in 1943, and 1946 saw more attacks on black individuals and communities as well as a revival of the Ku Klux Klan. When news spread that a lynch mob was descending on the black community in Colombia, Tennessee, civil rights activists rushed to the town, according to O'Brien, "fearing that racial violence would explode in the wake of World War II as it had following World War I" (4).

This remarkable book starts with the simple question of why it did not. To answer that question, O'Brien studied the Columbia case like a detective. Following a gripping retelling of the near-lynching of James Stephenson, O'Brien devotes six chapters to the various actors in the saga: local black leaders, black and white veterans, participants in the lynch mob, police, politicians, and organized civil rights activists. She concurs with Honey and Kersten that the War intensified racial politics, particularly for veterans, but points out that whites as well as blacks became more militant. What prevented racial tensions from exploding to the degree that they had in 1919 was the expansion of federal authority into local law enforcement, increased influence of liberal and left supporters of civil rights, and the ability of local African Americans to unite across class lines in defense of their community. Finally, expanded employment opportunities for white workers following the war decreased their participation in mob violence.

So why did increased militancy in the 1940 s not lead more quickly to the Civil Rights Movement that began in the 1950s? Both O'Brien and Honey blame the shifting priorities of civil rights activists. Working-class veterans were inspired by demands for voting rights, and they continued to support registration drives into the 1950s. The fight against segregation seemed less important to them, according to O'Brien, particularly as black job opportunities disappeared following the war. Honey emphasizes white workers' retreat from "civil rights unionism" during the Cold War, but also notes that "black workers did not usually lead broad social movements for equality" in the 1950s (239). It is telling that only one of Honey's interviewees, Leroy Clark, has more than a few sentences to say about the decade that many historians consider the most important in modern African American history. 
As former BSCP activist Bayard Rustin pointed out in 1965, the "decade that witnessed the decline of legal Jim Crow" also saw a dramatic increase in both unemployment and wage discrimination among African American workers. ${ }^{3}$ The most original sections of Honey's interviews deal with an effort to renew attention to employment as a civil rights issue in response to that observation. Swayed by the arguments of both Rustin and Randolph, Martin Luther King flew to Memphis in 1968, to support a sanitation workers' strike that he hoped would spark a revival of civil rights unionism. As Honey points out, King's presence brought national attention to black workers' economic plight at a time when many Americans were rejoicing the victory of the Civil Rights Movement. "We are saying now is the time to make real the promises of democracy," King declared at a strike rally. "Our struggle is for genuine equality which means economic equality" (292).

Interviews with participants in the Memphis strike remind readers that black workers had some success restoring job discrimination to the civil rights agenda in the late 1960s. Reminiscent of the BSCP's "manhood" campaign, strikers wore placards declaring "I Am a Man," which, according to James Robinson, was a protest against unfair treatment as much as against low wages. "'I Am a Man' [meant] that they weren't gonna take that shit no more," Robinson recalled. Honey's final interviews relate the damage that weakened labour laws and capital flight inflicted on Memphis unions in the 1970s and 1980 s, but union organizer Ida Leachman insists that civil rights unionism remains relevant for white as well as black workers:

I see labor and civil rights as intertwined. Because when you got rights on the job, it encompasses your civil rights, and when your rights on the job is violated, it also takes [away] your civil rights. The white women in the workplace, they too have civil rights trampled and even nowadays, white women catches [hell] pretty good. I guess it could be termed human rights. Yes, yes, because white workers have rights, and they have civil rights (348).

Leachman began her labour activism with a civil rights suit, which, according to Timothy Minchin, was typical of black working-class activists in the 1970s and 1980s. In fact, while most studies mark 1964 as the beginning of the end of civil rights activism, Minchin contends that the "Civil Rights Act of 1964 was critical in stimulating protest among black paper workers" in the late 1960s and 1970s. Alongside his award-winning Hiring the Black Worker: The Racial Integration of the Southern Textile Industry, 1960-1960, Minchin's The Color of Work illustrates how black workers transformed civil rights legislation into a weapon against barriers to employment and union representation that as 
A. Philip Randolph declared in 1962 were "as morally unjustified and organizationally indefensible as racially segregated public schools, housing, recreation, or transportation" $(10)$.

Because it was heavily unionized before 1964 , the paper industry provides a useful case study of organized labour's response to black activism in the absence of federal influence. While they excluded black workers initially, paper unions began to admit them into segregated locals in the 1930s and 1940s. Between 1945 and 1964, unions and managers cooperated to solidify a segregated seniority system that vitually eliminated the possibility of advancement for black union members. Segregated locals provided space for black workers to develop leadership and air some grievances, but whites maintained total control over union decision making. "What they done, they kind of had a little show," recalled black union president Robert Hicks, "[t]hey would give you an opportunity or a chance to say something at the [negotiations] . . but in total reality it was already cut and dried on what they were going to give you" (103).

As do each of the above studies, Minchin's demonstrates that workingclass African Americans were active participants in the evolution of federal employment policy. Just as the BSCP forced Roosevelt to create the FEPC before World War II, and as black workers in many industries called upon the FEPC and the NLRB to protect their earnings and union rights during and after the war, black paper workers demanded that the justice department enforce the anti-discrimination measures outlined in the Civil Rights Act. As William E. Gibbs testified in a case against the Weyerhauser Company, "you could file a grievance. Well they would keep hemming and hawing until it was finally torn up or filed away. And if you don't keep arguing and fussing and say, 'Well, if you don't do nothing about it, I'm going to the federal government.' Then they might make a move" (109).

And also like the other authors, Minchin ends on a pessimistic note. "As in other industries, it is somewhat ironic that the desegregation of the southern paper industry has occurred at a time of declining employment opportunities. The laboring jobs in which blacks had traditionally been placed were the jobs that were most easily replaced by mechanization" (214). Michael Honey also emphasizes the extent to which de-industrialization limited the gains of civil rights unionism. He closes Black Workers Remember with the story of a white worker who blamed his own unemployment on conservative tax and labor laws, but who still voted Republican because they had promised to crack down on African American "welfare chislers." The implication is that white workers remain "unwilling to join with their supposed adversaries in order to get out of the fix both are in" (373). Bates concludes that A. Philip Randolph's goals remain unfulfilled, and that his followers have succeeded only in "saving the idea of democracy for future generations to ponder (187). 
And yet the stories contained in these works indicate a much more material significance of black workers' activism. William Lucy, an organizer of the 1968 sanitation workers' strike who is now second in command of one of the nation's largest unions, insists that "there were tremendous gains made from the strike, not just in monetary gains for strikers but gains in the social and economic and political system here in Memphis" (314). Much more than an inspiring memory, according to Lucy, the strike led to the election of black judges and city officials, higher wages for all service workers in Memphis, and the spread of unions into other sectors of the city workforce. "The whole world has changed since back in the '50s," insisted James Robinson:

A lot of things changed for the worse. But I think the sanitation strike made a lot of difference for a lot of folks. Not just sanitation workers, all the workers. [It] made a lot of difference for the whole city. There are blacks in different places, like the bank and stuff like that. Before they'd just sweep the floor, now they're tellers. It's changin'. And somethin' I never would have though would happen: A black mayor of Memphis (308).

Robinson is clearly conflicted in his assessment of racial politics the past half century, but that should not lead us to underestimate the very tangible ways that he and other black working-people have transformed American politics. Largely as a result of black activism, African Americans are now nearly twice as likely as whites to belong to a union. Latinos are less likely than whites to belong to a union, but their unionization rate has increased $20 \%$ since 1983 . Women have increased their representation in the labor movement from $19 \%$ in 1962 to $42 \%$ in 2001 , roughly equal to their representation in the labour force in general. ${ }^{4}$ Historian Nelson Lichtenstein has pointed out recently that one of the most important features of the $21^{\text {st }}$ century workplace is the nearly unanimous acceptance of the anti-discrimination principles demanded by the BSCP in 1941 and codified by the 1964 Civil Rights Act. "This seems so commonplace and commonsensible, that we forget the radical character of this law."

\footnotetext{
' See Deborah Grey White, Too Heavy a Load: Black Women in Defense of Themselves, 1894-1994 (New York: Norton, 1999).

${ }^{2}$ See Lizbeth Cohen, Making a New Deal: Industrial Workers in Chicago, 1919-1939 (Cambridge: Cambridge University Press, 1990); and Meg Jacobs, "How About Some Meat?:" The Office of Price Administration, Consumption Politics, and State Building from the Bottom Up, 410-41.

${ }^{3}$ Bayard Rustin, "From Protest to Politics: The Future of the Civil Rights Movement," Commentary (February 1965): 25-31.
} 
${ }^{4}$ AFL-ClO, "Facts About Working Women," http://www.aflcio.org/women/wwfacts.htm; and "Unions Are Important for Minorities," http://www.aflcio.org/uniondifference/uniondiff12.htm.

${ }^{5}$ Nelson Lichtenstein, State of the Union: A Century of American Labor (Princeton University Press, 2002), 2.

Heather Ann Thompson, Whose Detroit? Politics, Labor, and Race in a Modern American City (Ithaca: Cornell University Press, 2001).

When one of the most economically vital areas of the United States becomes one of the least desirable places to live, and loses population like a melting ice cube loses mass, the situation cries out for an explanation. In recent years, historians have begun to supply answers to the question of what happened to Detroit, a project that has important insights for the status of other Rust Belt cities. Thomas Sugrue's Origins of the Urban Crisis is the best known contribution in this growing field. Heather Ann Thompson's Whose Detroit? takes a different tack than Sugrue, and in so doing highlights political dynamics in the Motor City that heretofore remained obscured. For Thompson, Detroit is a setting in which we can explore the development of American political liberalism and conservatism, as well as their more marginal variants. Thompson's book, though hampered somewhat by conceptual ambiguities, is a significant and original contribution to the field.

In Sugrue's analysis, Detroit and other cities are sites of conflict that fell into decline because of the failute to achieve integration of blacks at work, schools, and perhaps most importantly, in housing. This decline had early roots; Sugrue argues against those who see the 1960 s as a crucial turning point. Instead, the 1960s are the product of forces long in operation, most importantly, the multi-faceted exclusion of African Americans since their arrival en masse during World Wars I and II.

Thompson offers a different take on almost all of these points. First, she says it is wrong to see Detroit and liberalism as in decline; the city is still good for blacks, and liberalism offers more places and power for blacks than it did in the past. Labour went into decline, she agrees, but this was because of bad strategic choices. Second, the 1960 s were a crucial turning point; the bad decisions made by labour, specifically the United Auto Workers, occurred in that crucial decade. Last, though Thompson's is very much a story of conflict -- the title refers to continuing struggles of radicals, liberals, and conservatives to define Detroit's future - she emphasizes throughout the instances where blacks and whites worked together, whereas Sugrue showed the bitter conflicts of white vs. black. 